\title{
Application of EN-14065 in New Management of Hospital Laundry in Order to Reduce Hais Use of Antibiotics and to Slow The Development of Superbugs
}

\author{
Milena M. Grubor ${ }^{1}$, Dragana A. Kastratović ${ }^{1}$ Srdjan Z. Marković ${ }^{1}$, \\ Marija G. Grubor ${ }^{1}$
}

${ }^{1}$ Clinical Center of Serbia, Belgrade, Serbia

\section{SUMMARY}

Introduction Despite the steps taken to reduce HAls (Healthcare Acquired Infections), they still remain one of the world's leading and most costly healthcare challenges. Most are preventable. All are extremely costly in human and financial terms. The aim of this work is to summarize data on the persistence of different nosocomial pathogens on hospital textile and laundry, to reduce HAls, and use of antibiotics, with New Safety Management of Hospital Laundry by application of EN-14065 and PVA-bags, all in order to slow the development of resistant bacteria and prevent the spread of resistant infections.

Methodology We reviewed cited articles, and tested environmental friendly PVA-bags to proof minimizing the possibility of textiles posing as a source of infection.

Topic Reviewed cited articles confirmed existing persistence of the nosocomial pathogens on hospital surfaces. Efficiency of using PVA-bags to minimize transmission we confirmed in the Clinical Center of Serbia. The EN-14065 standard came into force in Serbia in 2012., and requires controlling the RABC system which provides an acceptable level of microbiological quality of laundered hospital laundry in hygienically clean state $\left(12 \mathrm{CFU} / 25 \mathrm{~cm}^{2}\right)$.

Conclusions Facts, that healthcare laundry continuous posing as a source of infection, and facts that HAls are most preventable, confirmed our need to make New Safety Management of Hospital Laundry by application the EN-14065 and PVA-bags to maintain effective Infection Control, which must be involved in Serbian HealthCare System, to slow the development of resistant bacteria (superbugs VRS, MRSA) all in order to reduce HAls, use of antibiotics, morbidity and mortality. Antibiotic-resistant bacteria - germs that don't respond to the drugs developed to kill them, threaten to return us to the time when simple infections were often fatal.

The best way to reduce occurrence of HAls will be, if new Insurance coverage regulations from Serbia eliminate reimbursement for HAls deemed preventable.

Keywords: New management; hospital-acquired infection; soiled linen; European Standard (EN 14065); PVA-Water soluble laundry bags 


\section{INTRODUCTION}

Healthcare Acquired Infections (HAIs), also called nosocomial infections, are infections that first appear between 48 hours and four days after a patient is admitted to a hospital or other health care facility. They include urinary tract, surgical site, lung and bloodstream infections[1]. They still remain one of the world's leading and most costly healthcare challenges. Most are preventable. All are extremely costly in human and financial terms.

Infection prevention policies do not address the most prevalent and overlooked component of the healthcare environmentSoft Surfaces. The potential for survival and spread of pathogens to and from humans and clothing or linens is shown by various laboratory studies. These studies show that survival does occur but varies considerably between different microbial strains and depends on factors such as temperature, relative humidity, type of fabric and inoculum size. Health and safety is paramount in a medical environment. Whether handling linens, instruments, or clothing, it is vital to eliminate the risk of cross infection to patients, staff and visitors.

Despite today's extensive efforts to prevent the spread of germs and bacteria, Healthcare Acquired Infections (HAIs) continue to be one of the world's most pressing and expensive healthcare problems. The transfer of Gram-positive bacteria, particularly MRSA and VRE, among patients is a growing concern[2].

\section{METHODOLOGY}

We reviewed cited articles, and tested environmental friendly PVA-bags to proof minimizing the possibility of textiles posing as a source of infection.

\section{TOPIC}

\section{Soft surfaces - the most overlooked prob- lem area in hospital}

While today's standards for preventing HAIs focus on patient screening, hand washing, hard surfaces, sterilizing and soft surfaces remain unaddressed. And this missing step is perhaps the greatest challenge to reducing HAIs.

HOSPITAL undergarments spread of pathogenic microorganisms in medical in- stitutions has become a major problem in the health sector [3]. Studies show that soft surfaces bed linens, curtains, uniforms and scrubs, can harbor bacteria and pathogens, causing recontamination during frequent contact. However, they are often ignored by infection prevention protocols [4].

The hospital laundry can be contaminated from the body of the patient, through employee's hands, from contaminated secondary air or other infected patients. Sheets, gowns, uniforms, towels, cleaning products (brooms, mops) and furniture in the patient's room are important to anyone who works or visits the hospital. They passage of infection, if not controlled [5]. Children and the elderly are especially vulnerable to infection, due to their less efficient immune system. The dirty laundry hospital identified as the source of a large number of pathogenic organisms, the actual risk of transmission of pathogens is belittled. For laundries, it's an opportunity to correct or improve their processes to ensure healthcare clients receive the highest-quality textile product possible.

Textiles contaminated with body substances can contain large numbers of microorganisms (106 - $108 \mathrm{cfu} / 100 \mathrm{~cm}^{2}$ fabric) [6].

Rotavirus is the most common cause of severe dearie in children (stomach flu), which result in admission to hospital for treatment, and only in America, about 55000 patients every year, and unfortunately, about 600 children succumb, and the world succumbs to a year and more than 600,000 cases. These are viruses that multiply in epithelial cells of the intestine, causing gastrointestinal problems, accompanied with diarrhea in humans and animals worldwide. Especially are vulnerable children and the elderly. They are spread by faecal-oral route. Infection is intense in the winter months. There is evidence that people underware who have incomplete control of the stool, even one-tenth of a gram $(1 / 10 \mathrm{~g})$ stool contains about a billion stool rotavirus. Washing to remove $99.99 \%$ of viruses, and then drying another $90 \%$ is eliminated, but still remained in underwear 100,000 live virus that can cause infection, so it is necessary ironing after washing, to the sick, and in private houses [7].

These findings are very important for patients who require a very long intensive inpatient treatment, because their immune system is very weakened from multiple reasons. 
For example, mortality caused by rotavirus in the general population is 1 in 10,000 , but because patients in intensive care, is 1 in 100 patients treated. Patients suffering from salmonella, 1 in 1000 has a chance to die in the general population, while patients in intensive care a chance to die there, is one on 25 . Adenovirus type 40 , causes diarrhea in children less intensity, less in adults, but if the patients got it with immunosuppression, such as cancer patients, mortality is around $50 \%[8]$.

\subsection{Pathogen Persistence}

Numerous studies indicate that pathogenic microorganisms persist in the inanimate environment. Kramer, et al. (2006) summarized data on the persistence of various pathogens on inanimate surfaces [9]. They report that most Gram-positive bacteria, such as Staphylococcus aureus (including MRSA), Enterococcus spp. (including VRE), or Streptococcus pyogenes survive for months on dry surfaces [10].

Many Gram-negative species, such as Acinetobacter spp., Escherichia coli, Klebsiella spp., Pseudomonas aeruginosa, Shigella spp., or Serratia marcescens can survive for months. A few others, such as Bordetella pertussis, Proteus vulgaris, Haemophilus influenzae, or Vibrio cholerae, however, persist only for days. Mycobacteria, including Mycobacterium tuberculosis, and spore-forming bacteria, including Clostridium difficile, can also survive for months on surfaces $[11,12]$.

Candida albicans, as the most important nosocomial fungal pathogen can survive up to four months on surfaces. Persistence of other yeasts, such as Torulopsis glabrata, was described to be similar (five months) or shorter (Candida parapsilosis, 14 days).

Most viruses from the respiratory tract, such as corona, coxsackie, influenza, SARS or rhino virus, can persist on surfaces for a few days. Viruses from the gastrointestinal tract, such as astrovirus, hepatitis A virus (HAV), polio, or rota virus, persist for approximately two months. Bloodborne viruses, such as hepatitis B virus (HBV) or human immunodeficiency virus (HIV), can persist for more than one week [13]. Herpes viruses, such as cytomegalovirus (CMV) or herpes simplex virus (HSV) types 1 and 2, have been shown to persist from only a few hours up to seven days [14].
Boyce, et al. 1997 sought to study the possible role of contaminated environmental surfaces as a reservoir of MRSA in hospitals through a prospective culture survey of inanimate objects in the rooms of patients with MRSA in a 200-bed university-affiliated teaching hospital. Thirty-eight consecutive patients colonized or infected with MRSA. Patients represented endemic MRSA cases. Ninety-six (27 percent) of 350 surfaces sampled in the rooms of affected patients were contaminated with MRSA [15].

It is very importent to stress that, when patients had MRSA in a wound or urine, 36 percent of surfaces were contaminated. In contrast, when MRSA was isolated from other body sites, only 6 percent of surfaces were contaminated (odds ratio, 8.8; 95\% confidence interval, 3.7-25.5; $\mathrm{P}<.0001)$. Environmental contamination occurred in the rooms of 73 percent of infected patients and 69 percent of colonized patients. Frequently contaminated objects included the floor, bed linens, the patient's gown, overbed tables, and blood pressure cuffs.

Sixty-five-65 percent of nurses who had performed morning patient-care activities on patients with MRSA in a wound or urine contaminated their nursing uniforms or gowns with MRSA. Forty-two percent of personnel who had no direct contact with such patients, but had touched contaminated surfaces, contaminated their gloves with MRSA [16].

Neely and Maley (2000) sought to examine the survival of several clinical and environmental staphylococcal and enterococcal isolates on fabrics and plastic commonly used in hospitals. One critical aspect of bacterial transfer is the ability of the microorganism to survive on various common hospital surfaces." The potential for survival and spread of pathogens to and from humans and clothing or linens is shown by various laboratory studies. These studies show that survival does occur, but varies considerably between different microbial strains and depends on factors such as type of fabric, temperature, relative humidity, and inoculum size [17].

In a study of fungi persistence, Neely and Orloff (2001) report that tests of the survival of Candida spp., a Fusarium spp., a Mucor spp., Aspergillus spp., and a Paecilomyces spp. on hospital fabrics and plastics indicated that viability was variable, with most fungi surviving at least one day but many living for weeks 
[18]. The researchers say their findings reinforce the need for appropriate disinfection and conscientious contact control precautions.

Bacterial survival, however, is not an entirely accurate measurement of viral survival. Viruses, in general, are far more resistant to disinfection by chlorination and detergents than are bacteria." They add, "If these viruses remain infectious throughout laundering, they may be transmitted to other individuals in a hospital or household setting through direct contact (laundry, hand, mouth) or through more indirect routes (mouth, hand, food, laundry).

This is no surprise given the fact that contaminated textiles often contain high numbers of microorganisms from body substances, including blood, stool, urine, skin, vomitus and other body tissues and fluids. According to the CDC, when textiles are heavily contaminated with potentially infective body substances, they can contain bacterial loads of six to eight logs CFU/100 $\mathrm{cm}^{2}$ of fabric [19]. Standard precautions must be observed while moving, loading, and unloading soiled textiles.

\subsection{Outbreaks associated with soft service textiles}

A number of studies are reported in which transfer via soft surface textiles was identified as the possible cause of an infection outbreak.

Study out of Denver in 2011 by Cervantes et al., white coats and newly laundered short-sleeve uniforms of 100 residents and hospitalists on an internal medicine service in a university affiliated hospital were cultured during an eight hour work day. They found that bacterial contamination occurred within hours after donning newly laundered uniforms. Colony counts of these newly laundered uniforms were essentially zero, but after just three hours of wear they were nearly $50 \%$ of those counted at eight hours [20].

Das et al. reported in 2002 of a multiple-antibiotic-resistant Acinetobacter baumanii that was first isolated from a patient in the general intensive care unit of a tertiary-referral university teaching hospital in Birmingham [21]. Similar strains were subsequently isolated from 12 other patients, including those on another intensive care unit within the hospital. Environmental screening revealed the presence of the multiple resistant Acineto- bacter species on fomite surfaces in the intensive care unit and bed linen [22].

In a nosocomial outbreak reported by Shah et al, 13 staff and 11 patients in an acute and chronic health care facility were infected with Microsporum canis [23]. The dermatophyte was apparently introduced into the facility by a single infected patient; the authors concluded that a likely mode of disease transmission was handling of contaminated laundry. Evidence of the fungus was found in stored linen.

\subsection{Ineffectiveness of Laundering}

Laundry processes do reduce the microbial load on clothing and linens. During ineffective laundering, however, data indicates that transmission of pathogens to other items in the load can occur. These risks have been assessed in a number of studies.

A study of home laundered uniforms involved taking surveillance cultures from five patients. Results showed that three of the patients were colonized with the same strain of microorganisms as that cultured from the healthcare providers uniforms. In a study in Great Britain in 2011, healthcare workers who washed their uniforms in domestic washing machines didn't kill all the MRSA and Acinetobacter [24].

According to AORN, surgical attire should be laundered in a healthcare accredited laundry facility. These facilities are preferred because they follow standardized industry standards for proper disinfection of fabrics. As we've discussed we know organisms can live and proliferate on fabrics and we depend upon the healthcare workers to effectively wash their uniforms to remove the germs. Our best practices recommend that these fabrics be washed after each day's wear [25].

\subsection{Standard Precautions and Linen Committees}

Standard Precautions combine the major features of Universal Precautions (UP) and Body Substance Isolation (BSI) and are based on the principle that all blood, body fluids, secretions, excretions except sweat, non-intact skin, and mucous membranes may contain transmissible infectious agents. Standard Precautions include a group of infection prevention practices that apply to all patients, regardless of 
suspected or confirmed infection status, in any setting in which healthcare is delivered. These include: use of gloves, hand hygiene; gown, mask, eye protection, or face shield, depending on the anticipated exposure [26].

We encourage infection control professionals to serve on their linen committees and if they don't have one, we encourage them to create one. The linen committee can have a dynamic combination of people - those who work solely in the linen room can tell you from a practical standpoint how to make the process more efficient. And infection control nurses can bring their unique perspective and expertise [27].

\section{PVA biodegradable water soluble laundry bags}

Equipment or items in the patient environment likely to have been contaminated with infectious body fluids must be handled in a manner to prevent transmission of infectious agents (e.g. wear gloves for direct contact, contain heavily soiled equipment, properly clean and disinfect or sterilize reusable equipment before use on another patient) [28].

Water soluble bags are new environmentally friendly products, specifically designed for use in health care facilities for disposal of contaminated hospital laundry, in order to avoid the risk of contamination and cross-infection of hospital staff, employees in the laundry, patients and visitors to healthcare institutions [29].

Water Soluble Laundry bags are specifically made for hospital and healthcare industry operators. These bags are made from water-soluble PVA film, which is a green environmental friendly material and it is $100 \%$ bio-degradable, and will not leave any environmental pollutant residue [30]. Once the bag is dissolved in the washing process, the solution will be decomposed to water and carbon dioxide [31]. These bags are impermeable to bacteria and virus. The Water-Soluble Laundry Bags are intended to enhance infection control processes in handling and transferring infected linens or other materials.

PVA fully-soluble laundry bags help to meet care guidelines by ensuring the safe isolation, transportation, and disinfections of soiled and compromised linens [32]. Soiled linen is placed into the bag, the bag is sealed using the integral cold water-soluble pink tie, and it is placed into an outer bag ready for transportation to the laundry washer. The cold water-soluble tie dissolves in the initial rinse cycle; the bag itself fully dissolves in the wash cycle (Figure 1).

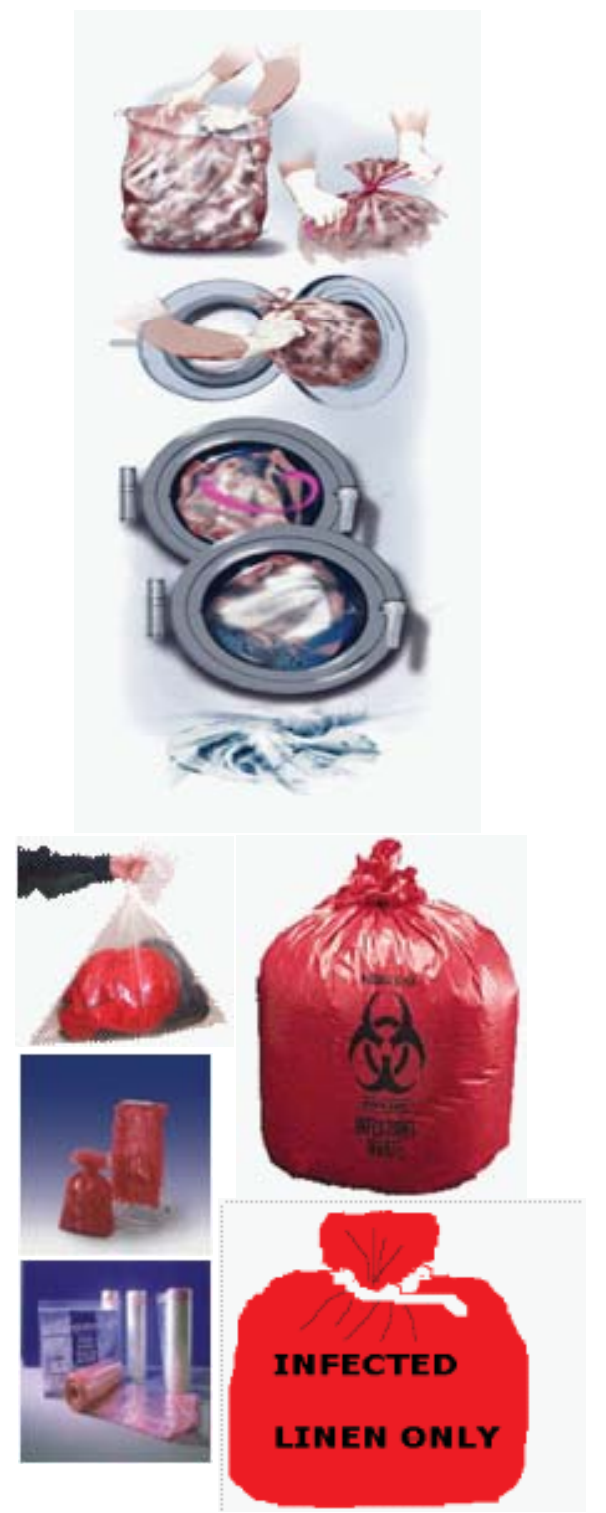

Bags are supplied interleaved on a roll reducing the risk of dispersing airborne viruses during dispensation. Laundry bags are available in several sizes in clear or red (Figure $1)$.

Application of $100 \%$ Water-Soluble Laundry Bag:

- The infected contents of the Laundry bag does not need to be handled by staff until the wash and drying cycles are completed. Consequently, this eliminates exposure to the contaminated material during the whole course of transferring, washing and drying [33].
Figure 1. New Procedure for the tretatment of hospital laundry [30] 
- The Water-Soluble Laundry bag will dissolve completely in water during the washing process.

- Water-Soluble Laundry bag leaves no potentially infected waste.

-Water-Soluble bags are anti-static, non-toxic, and fully biodegradable.

- Tests have verified that Water-Soluble bags are impermeable to bacteria and virus.

- Water-Soluble Laundry bag has an excellent gas barrier properties.

- Do not miss the Nan particles, and can be used in the protection of nuclear particles, or in nuclear medicine preventing staff from radiological contamination.

- Impervious for microbes, even rights protection of dissemination of dangerous microorganisms from hospital laundry in the nosocomial environment.

Clinical Centre of Serbia practical experience: In the Clinical Center of Serbia, we used sucesfully - tested PVA-bags for the first time in 2006, in our Clinic for Infectious and Tropical Diseases during outbreaks of bird flu to minimize the possibility of textiles posing as a source of infection or danger to the patient or healthcare worker. We confirmed that the Water Soluble Laundry Bag are convenient precaution tool that enables soiled linen handlers to isolate, store, transport and clean washable dirty items [34].

It is safe to say that the use of PVA bags in the handling of contaminated patients' undergarments, reducing the risk of excessive use of antibiotics remanded hospital effluent injected into the environment, usually not metabolized, but in its original form, as a result, we have increased resistance bacterial flora. The increasing resistance of bacteria and other flora has the effect, reduced adherence to the treatment of patients, economic loss, and increased mortality of patients treated, and dangerous environmental pollution with consequences not yet tested.

2.1. Hospital Textiles as a Possible Vehicle for Healthcare-Associated Infections

Contamination of textiles in healthcare settings is confirmed. Textiles are a common material in healthcare facilities; therefore it is important that they do not pose as a vehicle for the transfer of pathogens to patients or hospital workers. During the course of use hospital textiles become contaminated and laundering is necessary [35]. Laundering of healthcare textiles is most commonly adequate, but in some instances, due to inappropriate disinfection or subsequent recontamination, the textiles may become a contaminated inanimate surface with the possibility to transfer pathogens.

Healthcare professionals may unknowingly spread infectious germs by wearing scrubs and lab coats between work and home. In a recent study, up to $60 \%$ of hospital staff uniforms were found to be colonized with potentially pathogenic bacteria and drug-resistant organisms. Contamination has been shown to transfer from fabrics to hands [36]. "Hand imprint cultures demonstrated that these pathogens were easily acquired on hands." Once contaminated, uniforms and white coats can harbor pathogens for a long time. Neely and group summarized in the Journal of Clinical Microbiology in 2000 and 2001 multiple studies showing the survival of pathogens on fabric. They noted that MRSA in one study lived more than 20 days on cotton fabric and 40 days on polyester. The same holds true for VRE which survived more than 80 days on both fabrics.

It is thought that would be almost $30 \%$ nosocomial infections decreased with better hand washing and safe management of hospital facilities, in order to reduce the mortality and costs of treating patients. Therefore it can be said with certainty, that good management practices for hospital laundry is a very important factor in controlling the formation of nosocomial infections. It is therefore necessary to develop a standard for the management of hospital laundry, such as standards for the production and use of drugs.

\section{EN 14065, November 2002; ICS 07.100.99; 59.080.0}

Laundry plays a vital role in every healthcare facility's integrated infection prevention and control program. Studies have shown that, a textile can be considered a fomite, an object capable of carrying an organism and serving as a reservoir that can be involved in transmission. During a hospital stay, patients are literally surrounded and exposed to yards of healthcare textiles, including hospital staff sheets, work attire, towels, blankets, gowns, curtains and more.

3.1. Textiles-Laundry processed textiles -

Biocontamination control system 
This European Standard EN 14065 was approved by CEN on 23 September 2002. This European Standard shall be given the status of a national standard, either by publication of an identical text or by endorsement, at the latest by May 2003, and conflicting national standards shall be withdrawn at the latest by May 2003 [37].

In Serbia we used the identical text as ISO Standard from 2012. year.

Nowadays the need for the prevention of microbiological contamination of individuals, products, materials or environment is of increasing significance. Consequently, assured microbiological quality becomes necessary. Therefore the laundry industry is adopting new process control techniques to assure the microbiological quality of laundered textiles. The purpose of this standard is to provide a management system to deliver an agreed level of microbiological quality according to the intended use of the textile [38].

Hospital laundry management has become a fundamental point in any attendance centre. It is not only a matter of having the necessary linen available for both the patients and the professionals in the centre, but also that all the linen from a sanitary centre has to be considered to be contaminated by germs and as such must be treated in such a way that at the end of the cycle it can be supplied to the users and nurses free of any infectious pathogenic agents [39].

The laundry is one of the intervening factors in the fight to eliminate any source of microbiological contamination and the risk of recontamination to the patients.

Sensory cleanliness is obtained during the laundry cycle through physico-chemical treatments such as mechanical action, temperature, addition of detergents and auxiliary products, bleaching agents, dilutions and rinses in successive baths, in combination with sufficient time. With these procedures, most micro-organisms have a low probability of survival.

Principles of EN-14065:

- The list of microbiological hazard and a list of control measures a) Identification of microbiological hazard in every stage of the product code or staff; b) assessment and classification of risk levels bio contamination textiles in all phases of the management of hospital facilities, as a result of hazard; c) identification of the control measures in the elimination and reduction of bio-contamination of textiles in order to achieve the accepted level of microbiological quality in the use of hospital laundry. - Principle 2: Determination of control points/ step/and environmental conditions that can be controlled (control points) for the elimination of or risk reduction.

- Principle 3: Target levels and limit-limit values. Setting the threshold values at each control point which must not be exceeded, in order to ensure the microbiological quality of the processed for hospital services.

- Principle 4: Monitoring System. Setting the opinions or observations for monitoring control points.

- Principle 5: Corrective measures. Determination of corrective actions to be taken when monitoring shows that a particular item/procedures/operational stage/environmental conditions are not controlled.

- Principle 6: RABC system control process $[40,41,42]$.

As we will see, every step in the healthcare laundry process is exacting and regulated within an accredited laundry or laundry service, and this kind of quality may not be achievable in an unaccredited healthcare laundry [43]. In addition, the HLAC says that accredited healthcare laundries provide a level of efficiency that often can't be matched by in-house hospital laundries, and explains that today's healthcare laundries are state-ofthe-art, high-tech and efficient [44].

In addition to uniforms, bed linens, curtains and patient gowns should be washed at an accredited laundering facility [45].

In order to protect the environment in hospital of possible contamination of hospital laundry, and therefore patients and staff, it is necessary to change the procedure in the management of hospital laundry.

The use of water-soluble bags in Procedure secure management of contaminated patients' undergarments, fulfill the requirements for the prevention of nosocomial infections, are positioned in the application of EN 14065 is the imperative for safe hospital environment is safe handling of hospital laundry contaminated with blood, body fluids, excretions, and secretions, with special emphasis on the contaminated clothes of patients with, or clinically suspected to be suffering from the following diseases [46]: 
Table 1. The use of watersoluble bags with clinically following diseases [46]

\section{The use of water-soluble bags with clinically following diseases}

\begin{tabular}{lll} 
Ophthalmia neonatorum & Diphtheria & Syphilis \\
Cholera & Rubella (congenital) & Hepatitis B \\
Parvovirus (congenital) & Dysentery - shigellosis & Threadworm \\
\hline Clostridium difficile & Salmonellosis & Hepatitis C \\
Pertussis & Escherichia coli 0157 & Tuberculosis \\
Cryptosporidium & Scabies (if it is extensivan) & HIV \\
Plague & Gastroenteritis/children & Typhoid \&paratyphoid \\
Cytomegalovirus & Staphylococcus infection & Leprosy \\
Poliomyelitis & Giardiasis & Typhus \\
Diarrhoeal disease-unknown & Streptococcus pyogenes (groop A) & Measles \\
Ringworm & Hepatitis A & Meningitis
\end{tabular}

Good practice laundering is, of course, based on relevant technological laundry processes that ensure decontamination materials. Because of potential infection risk, it is crucial that healthcare textiles be properly processed and delivered to the customer in hygienically clean state $\left(12 \mathrm{CFU} / 25 \mathrm{~cm}^{2}\right)$. However, this is only part of the safe management of hospital facilities, because it is necessary to ensure that the hospital is guarded machine, sorted and transported correctly, and to minimize the possibilities of recontamination [47].

What the infection prevention community would like to see, however, is evidence from the medical literature addressing the efficacy of the new laundry chemicals on the market today.

\section{CONCLUSIONS}

- Healthcare-associated infection (HAI) outbreaks and patient notifications are often the result of either failures in infection control practices, or medications, or contaminated devices [48].

- Despite the steps taken to reduce HAIs (Healthcare Acquired Infections), they still remain one of the world's leading and most costly healthcare challenges. Most are preventable. All are extremely costly in human and financial terms.

- The most common nosocomial pathogens may well survive or persist on surfaces (especially on hospital laundry) more than for months, and can thereby be a continuous source of transmission.

- It is thought, that would be almost $30 \%$ nosocomial infections decreased with better hand washing and safe management of hospital facilities, in order to reduce the mortality and costs of treating patients [49].

- We confirmed, that the use of environmentaly friendla PVA-bags in Clinical Center of Serbia in 2006, during outbreak of Bird Flu effectively minimize the possibility of textiles posing as a source of infection or danger to the patient, or healthcare worker.

- The new EU-14065 standard came into force, and requires for the first time, that the safe management of hospital laundry must be classified as one of the most important links in the prevention of nosocomial infections, particularly in preventing the spread of lethal and potentially lethal bacteria.

- Hospital managers and health workers can no longer ignore the problem of safe management of hospital laundry and its role in the spread of nosocomial infections [50,51].

- Facts, that healthcare laundry continuous posing as a source of infection, and facts that HAIs are most preventable, confirmed our need to make New Safety Management of Hospital Laundry by application the EN-14065 and PVA- Bags to maintain effective Infection Control, which must be involved in Serbian Health Care System, to slow the development of resistant bacteria (superbugs VRS, MRSA) all in order to reduce HAIs, use of antibiotics, morbidity and mortality [52].

- Antibiotic-resistant bacteria-germs that don't respond to the drugs developed to kill them, threaten to return us to the time, when simple infections were often fatal.

- The New Safety Management will strengthen Serbian own-health surveillance efforts to combat resistance.

- The best way to reduce occurrence of HAIs will be, if new Insurance coverage regulations from Serbia eliminate reimbursement for HAIs deemed preventable. 


\section{REFERENCES}

1. Weiner-Well, Y., Galuty, M., Rudenksy, B., Schlesinger, Y., Attias, D., Yinnon, A.M. (2011). Nursing and physician attire as possible source of nosocomial infection. American Journal of Infection Control. 39 (7), 555-559.

2. Pulvirenti JJ, et al. Infect Control Hosp Epidemiol 2002; 23: 641-7.

3. Wilson JA, Loveday HP, Hoffman PN, Pratt RJ. Uniform: an evidence review of the microbiological significance of uniforms and uniform policy in the prevention and control of healthcare-associated infections. Report to the Department of Health (England). J Hosp Infect 2007;66:301-7.

4. Sifuentes LY, Gerba CP, Weart I, Engel Brecht K, Koenig DW. Microbial contamination of hospital reusable cleaning towels. Am J Infect Control. 2013 Oct; 41(10):912-5.

5. Hota B: Contamination, disinfection, and crosscolonization: are hospital surfaces reservoirs for nosocomial infection? Clinical Infectious Diseases 2004, 39:1182-1189.

6. Otero R.B. Soiled hospital linens-Are they a threat? Laund. News. 1986; 12:17.

7. Ansari SA, Sattar SA, Springthorpe VS, Wells GA, Tostawaryk W: Rotavirus survival on human hands and transfer of infectious virus to inanimate and nonporous inanimate surfaces. Journal of Clinical Microbiology 1988, 26: 1513-1518

8. Butz AM, Fosarelli P, Dick J, Cusack T, Yolken R: Prevalence of rotavirus on high-risk fomites in daycare facilities. Pediatrics 1993, 92: 202-205.

9. Kramer., et. all. (2006): How long do nosocomial pathogens persist on inanimate surfaces? BMC Infectious Deseases, Central page 1-8.

10. Duckro AN, Blom DW, Lyle EA, Weinstein RA, Hayden MK: Transfer of vancomycin-resistant enterococci via health care worker hands. Archives of Internal Medicine 2005, 165: 302-307.

11. Hanna H, Raad I, Gonzalez V, Umphrey J, Tarrand J, Neumann J, Champlin R: Control of nosocomial Clostridium difficile transmission in bone marrow transplant patients. Infection Control and Hospital Epidemiology 2000, 21: 226-228.

12. Verity P, Wilcox MH, Fawley W, Parnell P: Prospective evaluation of environmental contamination by Clostridium difficile in isolation side rooms. Journal of Hospital Infection 2001, 49: 204-209.

13. Bond WW, Favero MS, Petersen NJ, Gravelle CR, Ebert JW, Maynhard JE: Survival of hepatitis B virus after drying and storage for one week. The Lancet 1981, I: 550-551

14. Sattar S, Lloyd-Evans N, Springthorpe VS: Institutional outbreaks of rotavirus diarrhoea: potentia I role of fomites and environmental surfaces as vehicles for virus transmission. Journal of Hygiene, Cambridge 1986, 96: 277-289.

15. Boyce JM, Potter-Bynoe G, Chenevert C, King $\mathrm{T}$ : Environmental contamination due to methicillin -resistant Staphylococcus aureus: possible infection control implications. Infection Control and Hospital Epidemiology 1997, 18: 622-627

16. Overton E (1988) Bed-making and bacteria. Nursing Times, 85(9): $69-71$.

17. Neely AN, Maley MP. Survival of enterococci and staphylococci on hospital fabrics and plastic. J Clin Microbiol 2000; 38(2): 724-726.

18. A.N. Neely and M.M. Orloff, "Survival of some medically important fungi on hospital fabrics and plastics", J CLIN MICR, 39(9), 2001, pp. 3360-3361

19. Centre for Disease Control (2000): Washing Infected Material, Atlanta, USA, Central Sterilizing Club. Laundry Working Group Discussion Paper. September 1998.

20. Cervantes et al. Newly Cleaned Physician Uniforms and Infrequently Washed White Coats Have Similar Rates of Bacterial Contamination After an 8-Hour Workd: Journal of Hospital Medicine 2011;000:000-000.VC 2011 Society of Hospital Medicine uniforme

21. Das I., Lambert P., Hill D., Noy M., Bion J., Elliott T. Carbapenem-resistant Acinetobacter and role of curtains in an outbreak in intensive care units. J. Hosp. Infect. 2002; 50:110-114

22. Webster C, Towner KJ, Humphreys H: Survival of Acinetobacter on three clinically related inanimate surfaces. Infection Control and Hospital Epidemiology 2000, 21: 246.

23. Shah P.C., Krajden S., Kane J., Summerbell R.C. Tinea corporis caused my Microsporum canis: Report of a nosocomial outbreak. Eur. J. Epidemiology. 1988; 4: 33 - 38.

24. Lakdawala N, Pham J, Shah M, Holton J. Effectiveness of low-temperature domestic laundry on the decontamination of healthcare workers' uniforms. Infect Control Hosp Epidemiology. 2011 Nov; 32(11):1103-8

25. Association of Perioperative Nurses (AORN). Recommended Practices for Surgical Attire. November 2010.

26. "Nursing and physician attire as possible source of nosocomial infections"; American Journal of Infection Control, September 2011

27. Collins A.S. Preventing Healthcare-Associated Infections. In: Hughes R.G., editor. Patient Safety and Quality: An Evidence-Based Handbook for Nurses. Chapter 41. Agency for Healthcare Research and Quality; Rockville, MD, USA: 2008. pp. 547-575.

28. Centers for Disease Control. Update: universal precautions for prevention of transmission of hu- 
man immunodeficiency virus, hepatitis $B$ virus, and other bloodborne pathogens in health-care settings. MMWR Morb Mortal Wkly Rep 1988;37:37782, 387-8.

29. Vinyl acetate, polyvinyl acetate and Polyvinyl alcohol. In: Some Monomers, Plastics, and Synthetic Elastomers, and Acrolein. IARC Working group, feb. 7-13,1978, Lyon, France

30. Biodegradable /Water - Soluble Bags; www. bagco.com.au/biodegradable_water-soluble bags

31. Taniguchi, J. \& Ohkita, K. (1977) Testing paper for measuring poly(vinyl alcohol) concentration. Japanese Patent 7765,495, 30 May, to Shikishima Spinning Co., Ltd [Chem. Abstr., 88, 54762k]

32. World Health Organization (WHO). International Agerny for Research on Cancer (IARC); Lyon, France. IARC Monographs on the Evaluation of the Carcinogenic Risk of Chemicals to Man, Vol. 19, pp. 341-366.

33. Pyrek K. Trends in Infection Prevention and Control: Healthcare Textiles: Laundry Science and Infection Prevention. Infection Control Today. March 2011.

34. NHS Executive (1995) "Hospital Laundry Arrangements for Used and Infected Linen" Health Service Guidelines (HSG(93)18) Lancashire

35. Barrie, D (1994) "Infection Control in Practice: How hospital linen and laundry services are provided" Journal of Hospital Infection 27 pp 219-235.

36. Sasahara T, Hayashi S, Morisawa Y, Sakihama T, Yoshimura A, Hirai Y. Bacillus cereus bacteremia outbreak due to contaminated hospital linens. Eur J Clin Microbiol Infect Dis. 2011 Feb; 30(2):219-26.

37. Fijan S., Šostar-Turk S., Cencič A. Implementing hygiene monitoring systems in hospital laundries in order to reduce microbial contamination of hospital textiles. J. Hosp. Infect. 2005; 61:30-38. EN STANDARD -RABC

38. Orr K.E., Holliday M.G., Jones A.L., Robson I., Perry J.D. Survival of enterococci during hospital laundry processing. J. Hosp. Infect. 2002; 50:133 - 139.

39. Smith J.A., Neil K.R., Davidson C.G., Davidson R.W. Effect of water temperature on bacterial killing in laundry. Infect. Control. 1987; 8:204 - 209.

40. Textiles-Laundry Processed Textiles-Bio contamination Control System; EN 14065. 2003.

41. Oliphant J.W., Gordon D.A., Meis A., Parker R. $Q$ fever in laundry workers presumably transmitted from contaminated clothing. Amer. J. Hyg. 1949; 47:76-81.

42. Walter WG, Schillinger JE. Bacterial survival in laundered fabrics. Appl Microbiol 1975:29:368-73.

43. NHS Purchasing and supply Agency (2003) Mar- ket testing of laundry and linen services, Procurement Guide

44. Healthcare Laundry Accreditation Council (HLAC). Hygienically Clean Textiles. Available at www.hlacnet.org/standards.php. January 2012

45. Textile Rental Services Association (TRSA). Standard for Producing Hygienically Clean Reusable Textiles. May 2013.

46. Fijan S, Sostar-Turk S, Cencic A. Implementing hygiene monitoring systems in hospital laundries in order to reduce microbial contamination of hospital textiles. J Hosp Infect 2005;61:30-8.

47. Healthcare Laundry Accreditation Council. Accreditation Standards for Processing Reusable Textiles for Use in Healthcare Facilities. April 2006.

48. World Health Organization (WHO) Guidelines on Hand Hygiene in Health Care, 2009.

49. Guidelines for environmental infection control in health-care facilities. MMWR - Morbidity \& Mortality Weekly Report 2003, 52:1-44.

50. CDC (2001) MMWR 50 (RR05), 1-43.

51. CDC (1999) MMWR - Morbidity \& Mortality Weekly Report 48, 707-710.

52. I.A. Holder and A.N. Neely, "FEAR OF MRSA POTENTIAL FOR FUTURE DISASTER”, Burns, 24(2), 1998, pp. 99-103 


\section{Primena EN-14065 u novom menadžmentu bolničkog rublja u cilju smanjenja bolničkih infekcija upotrebe antibiotika i razvoja supermikroba}

Milena M. Grubor ${ }^{1}$, Dragana A. Kastratović ${ }^{1}$, Srdjan Z. Marković ${ }^{1}$, Marija G. Grubor ${ }^{1}$

${ }^{1}$ Klinički Cenrat Srbija, Beograd, Srbija

\section{KRATAK SADRŽAJ}

Uvod Uprkos preduzetim koracima da se smanji nastanak bolničkih infekcija, one i dalje ostaju vodeći svetski najskuplji zdravstveni izazovi. Većina se može sprečiti. Sve su infekcije izuzetno skupe i odnose veliki broj ljudskih života. Cilj rada je, da sumira podatke o perzistenciji različitih bolničkih patogena na bolničkom rublju, kako bih se smanjile bolničke infekcije i upotreba antibiotika, uvođenjem novog upravljanja bolničkim rubljem primenom EN-14065 i PVA- kesa, i usporio razvoj rezistentnih bakterija i sprečilo širenja infekcija.

Metodologija Pregledom citiranih artikala, i testiranjem ekoloških PVA- kesa potvrditi mogućnosti redukcije da bolničko rublje predstavlja izvor bolničkih infekcija.

Edukativna tema Pregledom navedenih artikala potvrđena je perzistencija bolničkih patogena na bolničkom rublju. Efikasnost korišćenja PVA-kesa u smanjenju prenosa patogena potvrđena je u Kliničkom centru Srbije.

EN - 14065 je stupio na snagu u Srbiji 2012. godine, a zahteva kontrolni biološki sistem pranja i određuje prihvatljiv nivo mikrobiološke kvaliteta opranog bolničkog rublja (12 CFU/25 $\mathrm{cm}^{2}$ tekstila).

Zaključak Da bolničko rublje kontinuirano predstavlja izvor infekcija, a većina infekcija je preventabilna, potvrđuje potrebu izrade novog menadžmenta upravljanja bolničkim rubljem kroz primenu EN 14065 I PVA-kesa, u cilju efikasne kontrole infekcija. Novi menadžment mora biti uključen u Zdravstveni sistem Srbije, kako bi usporili razvoj supermikroba (VRS, MRS), redukovali infekcije, upotrebu antibiotika, oboljevanje i smrtnost. Razvoj supermikroba preti da nas vrati u vreme, kada nam je najlakša infekcija bila fatalna.

Novi propisi zdravstvenog osiguranja u Srbiji, treba da eliminišu naknade za sve bolničke infekcije za koje se mogu sprečiti. To je najbolje rešenje za ovaj rastući problem.

Ključne reči: Novi menadžment; Bolničke infekcije; kontaminirano bolničko rublje; Evropski standard (EN 14065); PVA-vodorastvorljive kese za bolničko rublje 